\title{
Commodifying Pilgrimage: Emerge of Ziarah Ritual Commodification in Mount Kawi
}

\author{
Dwi Sulistyorini $^{1}$, Bani Sudardi ${ }^{2}$, Warto $^{3}$, and Mahendra Wijaya ${ }^{4}$ \\ \{shoelistr@yahoo.co.id ${ }^{1}$, banisudardi@yahoo.co.id ${ }^{2}$, warto_file@yahoo.co.id ${ }^{3}$ \& \\ mahendrawijaya_uns@yahoo.co.id $\left.{ }^{4}\right\}$ \\ ${ }^{1}$ Lecturer of Malang State University, docotral candidate for cultural studies at Universitas \\ Sebelas Maret, Surakarta, Indonesia \\ 2,3,4 Universitas Sebelas Maret, Surakarta, Indonesia
}

\begin{abstract}
The form of Pesarean in mount Kawi which is currently known as one of the tourism icons of Malang and National does not occur suddenly. Changes and the various complexities of problems that occur within them are a form of cultural mechanisms that lead to a form of commodification of cultural products. By using ethnographic research methods during the period of 2017-2019 the following results are obtained. The commodification of the pilgrimage ritual in mount Kawi occurred in three phases of development during the 1960s, 1980s, and 2000s. Various developments that occur refer to the efforts of the development and development of the pilgrimage ritual area into cultural consumption goods. Through capitalist mechanisms and capital control, the sacred activities carried out by adherents of beliefs based on religious values are transformed into a form of market interest by prioritizing the principle of exchanging economic values to the agents involved. The government, managers and communities are agents who are directly involved in this process.
\end{abstract}

Keywords: commodification, mount kawi, pilgrimage, ritual

\section{INTRODUCTION}

Mount Kawi is one of the sacred mountains in Malang Regency, East Java, Indonesia. The community has considered Mount Kawi as a sacred mountain because there are historical and magical events that accompanied it from the days of the Javanese empires to the time of the struggle for independence. Until now, Mount Kawi has been crowded with people from various ethnic, religious and belief backgrounds [1]. They came to visit Mount Kawi to do a number of rites that they believed would give blessings in their life.

The existence of Mount Kawi in the middle of community's life is not only interpreted as a sacred mountain's rite which has functions as a medium of religious actualization. However, historically, Mount Kawi is closely related to history of Javanese kingdoms and history of Indonesia's struggle for independence. In Javanese chronicle (Babad Tanah Jawa) it is noted that in around the 9 th century AD, Mpu Sindok from Mataram kingdom established a hermitage 
as a place of seclusion which is now known as Kawi palace [2]. Not only that, King of the Kingdom of Kediri, Prabu Kamesawara, also once exiled and meditated in this region.

The famous name of the Mount Kawi as a holy place is also triggered by the burial of two important figures in history of Indonesian nation's struggle in seizing independence and the spread of Islam in Java region. Theese two figures are Raden Zakaria II or better known as Mbah Djoego and R. M. Iman Soedjono. Both of them were also known as medical experts, community leaders and role models, and loyal warriors of Prince Diponegoro while fighting against the Dutch in 1825-1830 [3], [4]. Eyang Djoego, whose real name is Kanjeng Kyai Zakaria II, a scholar of the Mataram palace, while R.M. Faith Soedjono was a nobleman who became the warlord of Prince Diponegoro of Yogyakarta palace. The two figures were spiritual advisers to Prince Diponegoro who fled to the East after Prince Diponegoro was captured by the Dutch, in 1830 [5], [6].

These days, areas in Mount Kawi, visitors who came from various destinations visit especially Mount Kawi Graveyard. Pilgrims who come are not only Javanese, but also many who are of ethnic Chinese origin [7]. As a destination for pilgrims from various ethnic backgrounds and beliefs, the Mount Kawi pesarean graveyard as a cultural space with Majati society, they are Madura, Javanese, and Chinese. Many people from various ethnic groups come to just go on pilgrimages or depend their lives to rituals at the Mount Kawi Graveyard. As a result, the cultural features of Mount Kawi graveyard turn into Mount cultural arena. Mount Kawi Graveyard is a meeting point and intersection of various cultures that characterizes this place until now.

As a cultural arena which unites various people from different ethnic backgrounds and beliefs, Mount Kawi Graveyard emerges a distinctive socio-cultural life style. Success of ritual which has been carried out is usually followed by hold a puppets show (wayang kulit), salvation, giving away wall clocks, lights, and so on. All of these gifts have Chinese letters on them. As a result, decoration of Mount Kawi Graveyard room is characterized by Chinese. Mount Kawi Graveyard complex has grown as a distinctive cultural space because of acculturation and assimilation between cultures there. This can be seen from buildings around graveyard which are a blend of Chinese and Javanese culture. The form of cultural assimilation can be seen from the existing of ritual place, such as mosque, pagoda, the temple of Kuan Im Goddess which stands side by side there. Meanwhile, the form of acculturation can be seen from ritual processions and Chinese-Javanese building architecture.

High number of pilgrims who came to the Mount Kawi temple also had an impact on the economic, social and cultural life that was there. Presence of various communities from various groups has gradually changed the economic, social and cultural life of people slowly [8]. On the other hand, large number of visitors who come to Mount Kawi each year provides an opportunity for some of capital owners to commodify these cultural artifacts that used to function as pilgrims' ritual rooms are also use as religious tourism spots. This condition raises problems related to the commodification that occurs in Mount Kawi Graveyard as a cultural artifact. This study discusses the emergence of commodification of pilgrimage rituals at Mount Kawi. This problem is significant because the form of Mount Kawi Graveyard which is currently known as one of Malang and National Regency tourism icons does happen suddenly. Changes and the various complexities of problems that occur there are a form of cultural mechanisms that lead to a form of commodification of cultural products. 


\section{METHOD}

This research was conducted at Mount Kawi. It is belong to the administrative area of Wonosari village, Wonosari sub-district, Malang Regency, East Java. The study was conducted during the period 2017-2019. The researcher used an ethnographic method, with participatory involvement of researchers in the research area in order to understand the phenomena that occur based on the context as natural as possible. This research is a field research. To collect data, researchers used qualitative research data collection techniques proposed by Cresswell [9]. Therefore, to collect data related to the purpose of the problem in this study carried out by 1) in-depth interviews, 2) participant observation, and 3) document study. This study uses research instruments in the form of 1) researchers, 2) interview guides, 3) field notes, and 4) record instruments.

In this study, data analysis was carried out by display, reduction, and conclusion. Display includes these activities 1) processing and preparing data derived from interview transcriptions, field notes, and documents. Various collected data are classified and arranged according to their categories according to the source, 2) reading all the information that has been obtained and reflecting on the overall meaning. This is related to ideas and general information obtained during the process of reading the data that has been collected. Data reduction is done by 1) filtering various data needed in accordance with the purpose of the study, 2) coding each data that has been obtained based on the type. In this process researchers share information that has been obtained into segments to be interpreted. Concretely, this is done by collecting written and image data that has been collected previously to be segmented into categories and labeled with special terms, 3) after coding is done, settings, people, categories and themes are carried out in accordance with the purpose of the study, and 4) linking each theme and description that has been obtained for later analysis. The last step is to draw conclusions by interpreting and signifying data.

\section{RESULT AND DISCUSSION}

The form of Mount Kawi Graveyard which is currently known as one of the tourism icons of Malang District and Indonesia does happen suddenly. Changes and the various complexities of problems that occur there are a form of cultural mechanisms that lead to a form of commodification of cultural products.

The ritual that took place in Pesarean Mount Kawi actually happened since Mbah (grandfather) Djoego was buried in Wonosari village, Malang district. Nevertheless, Mount Kawi found it's momentum in 1931 when a Tionghoan named Tan Yam made a pilgrimage to Mount Kawi. Feel that he was getting peace of life, finally Mr. Yam decided to stay there and serve Eyang (grandfather) Djoego and R.M. Faith Soedjono by built a road from graveyard to area near terminal. Tan Kie Yam passed away in 1964. The presence of Mr.Yam in Wonosari has been encouraged other Tionghoan to visit Mount Kawi.

Besides that, a Tionghoan named Ong Hok Liong, who still a relative of Tan Kie Yam, known as a Bentoel cigarette businessperson. When he and his wife visited Tan Kie Yam, they met Mbah Djuwul and were given two bentul seeds (mountain plants like taro), then came the inspiration to both of them to try make cigarettes with Bentoel stamp. Finally, the business made it to the present. News about the success of Ong Hok Liong's business finally spread everywhere, so that many Tionghoans want to visit Mount Kawi.

The large number of visitors who come to Mount Kawi Graveyard provides economic opportunities that can be obtained by various parties in this region. Level of economic income potential that can be obtained from economic transactions that occur in the pilgrimage ritual 
procession at Mount Kawi Graveyard is the main factor that has led to the commodification of pilgrimage ritual in Mount Kawi Graveyard. Opportunities which emerge from the pilgrimage ritual process affect almost all sectors of people's lives there. In addition, it also affects parties who are outside pilgrimage ritual management sector of Mount Kawi Graveyard, such as Malang Regency local government and Malang Regency Tourism Office. Based on this case, there were various growth and developments, both in small and large scale, in Mount Kawi Graveyard area.

In general, the patterns of development that occur in Mount Kawi Graveyard can be observed through three stages of development that occur based on the time period This can be seen in the following picture.

\begin{tabular}{|c|c|c|}
\hline $\begin{array}{l}\text { - The development of } \\
\text { adequate road access by } \\
\text { the government from the } \\
\text { Kepanjen area to } \\
\text { Wonosari Village } \\
\text { - In 1965, the asphalt road } \\
\text { began to spread evenly } \\
\text { along the road to } \\
\text { graveyard. } \\
\text { - Many buildings have } \\
\text { dual function, such as } \\
\text { large house that is } \\
\text { functioned as a } \\
\text { worshipping temple is } \\
\text { used for worship of } \\
\text { Muslims and Confucians } \\
\text { and prayer place for } \\
\text { Dewi Kwan-Im and } \\
\text { Ciamsi. }\end{array}$ & $\begin{array}{l}\text { - Early development stage } \\
\text { began with large scale } \\
\text { development } \\
\text { - Construction of mosques is } \\
\text { ten times larger than the } \\
\text { earlier building } \\
\text { - Asphalted road } \\
\text { - Availability of a large } \\
\text { parking area } \\
\text { - The establishment of } \\
\text { lodgings, restaurants and } \\
\text { gift shops and food vendors } \\
\text { and ritual necessities }\end{array}$ & $\begin{array}{l}\text { The Malang Regency Government, } \\
\text { through the Regent of Sujud } \\
\text { Pribadi, set Wonosari Village as a } \\
\text { "Ritual Village" } \\
\text { In 2015, Malang regent Rendra } \\
\text { Kresna, through the Tourism Office } \\
\text { set Wonosari Village as a "Tourism } \\
\text { Village" } \\
\text { In 2018, the Mount Kawi } \\
\text { Graveyard area was planned as one } \\
\text { of the centers of the Tourism } \\
\text { Authority Agency. The Central } \\
\text { Government, through the Malang } \\
\text { Regency Regional Government, } \\
\text { provides } 150 \text { hectares of land as a } \\
\text { location for the development of } \\
\text { tourist areas in this region. }\end{array}$ \\
\hline 1960’s & 1980’s & 2000 - currently \\
\hline
\end{tabular}

Fig 1. Commodification Development Stage Ritual Pilgrimage at Mount Kawi Graveyard

In the 1960s and 1980s, the development was directed towards physical development in the Mount Kawi Graveyard complex. However, since 2000s, the commodification of these cultural products began to appear. By looking at the opportunities for economic transactions that occur and the large number of visitors, Malang Regency government looks at the potential of regional income that can be taken from religious activities in Mount Kawi Graveyard.

Begin with efforts to change the representation of religious activities in Mount Kawi Graveyard to not only be a sacred space, but also a profane space, the government established this area as a ritual village followed by the establishment of a tourist village in 2015. In this mechanism, the regional government tried to create a new market mechanism, namely tourism market, by structuring exchange social networks by offering supply and demand [10]. It means that, the government sees opportunities for the value of economic exchange that can be obtained from various tourism activities around Mount Kawi Graveyard.

Despite changes in the representation of Mount Kawi Graveyard that carried out by the government, it can be seen that there is no conflict carried out by local managers and the community. Effort in commodifying the pilgrimage rituals to the wider community as cultural consumption goods get two legitimation forms of reinforcement, which are both the trigger variables of this support. First, the variable of emergence of commodification internally, namely 
a) motivation to improve the welfare of managers (Ngesti Gondho Foundation), Government of Wonosari Village and Malang Regency, and local communities and b) development of a pilgrimage ritual area. Second, the variable emergence of external commodification, namely a) increase in income of the regional tourism industry, government hegemony, and capitalism and cultural industries.

These various factors are the main variables that have led to the commodification of the pilgrimage ritual at Mount Kawi Graveyard. Malang Regency Government through Malang Regency Tourism Office as regulator of policy makers can be seen as a system with a dominant ideology that is able to move the groups below it [11]. This mechanism runs smoothly through a hegemonic system. Through various regional development regulations and plans, both local managers and communities contribute to the planned flow of developments and forget a little about the impacts that can be generated from the ongoing commodification process. This mechanism can work well because the ideas of the ruling class will be the dominant idea [12].

Even so, it should also be recognized that in the ongoing commodification process there is a small form of resistance carried out by the manager towards the commodification of the pilgrimage ritual at tMount Kawi Graveyard. With regional development carried out internally by the manager, without any government intervention, the manager felt that the direction of the development of Mount Kawi area as a tourist area was only superimposed on the fame of the name Mount Kawi Graveyard which had been known to the wider community, even to foreign countries. In other words, the fame of Mount Kawi is made into a form of commodity that is reproduced in the form of a representation of "cultural splendor" in the form of a duplicate tourist area. Borrowing Baudrillard's term [13], the name Pesarean Mount Kawi is a simulacra for various forms of cultural products which will later be built as a tourist area that stands around the graveyard complex. If this happens, the question of the existence of sacred spaces and the authenticity of various cultural products currently in Mount Kawi is another matter.

This effort is clearly seen in the planned Mount Kawi area as one of the centers of the Tourism Authority Agency. The Central Government, through the Regional Government of Malang Regency, provides a land area of 150 hectares as the location of the development of tourist areas in this region. The plan is for increasing the number of visitors, will be built a miniature such as the Beautiful Indonesia Miniature Park which is equipped with a variety of rides, lodging ranging from jasmine classes to star hotels, rest areas, restaurants, to gift shops. The development of this area is planned to involve the local community. People can make their houses as guest house for visitors who come.

This shows that the various developments that happen at this time, focus on an effort to develop a tourist area that is oriented to foreign exchange earnings and economic benefits. This mechanism shows the thing mentioned by Adorno [14], that falsehood and commodities in the capitalist world are almost identical. That is, the various needs and enjoyment of cultural experiences that are embedded in the authenticity of the ritual activities in Mount Kawi Pesarean are slowly being replaced by a new form of enjoyment in the form of new cultural products. This mechanism works by building a number of new fake needs in the community regarding tourism needs. The religious tourism authenticity that has been embedded in the form of pilgrimage rituals will be replaced with more general cultural tourism.

The process that happen will become a problem later on. This is as shown by Bruckermann [15] that efforts to hybridize local-global culture will damage universal and local purity authorities under capital. In this process, it is very possible for local and global identity ambiguity to happen [16], [17]. In the process there will be a tension to become dominant [18]. There is competition in itself to be more prominent than others. In this power relation, the national and regional governments tend to provide opportunities for transnational capital 
corporations to make a profit. With such a large development plan, even though there is an effort to involve the community in it, it is possible to create a gap of interest to get better benefit for big investors in the current transaction.

On a broader scale, the emergence of commodification of pilgrimage rituals in Mount Kawi Graveyard is similar to the process of commodification in Chinese [19]. The research shows that the commodification of religion and the worship of phutha phanit specifically in Thailand are the result of economic exchange, symbolic exchange and semiotics of faith, experience, image and money. Capitalism is able to change or create a new view of religious teaching that exist in Buddhism in Thailand. Buddhism in Thailand is a new form of religion which has been formed through the process of localism and syncretism. On the other hand, this new form has produced a new religious meaning based on economic values [20], where individual well-being, luck and success are positioned as the main things rather than conventional Buddhist religious teachings. That is, capitalism and the market have been able to change or contribute to shaping the beliefs that exist in a religion [21].

\section{CONCLUSION}

The commodification of pilgrimage ritual at Mount Kawi occurred in three phases of development during the 1960s, 1980s, and 2000s. Various developments that occur refer to the efforts of growth and development of the pilgrimage ritual area into cultural consumption goods. Through capitalist mechanisms and capital control, the sacred activities carried out by adherents of beliefs based on religious values are transformed into a form of market interest by prioritizing the principle of exchanging economic values to the agents involved. The government, managers and communities are agents who are directly involved in this process.

\section{REFERENCES}

[1] D. Sulistyorini, B. Sudardi, Warto, and M. Wijaya, "Cultural Tourism to Pesaraen Kawi Mountain as a Cultural of Cultural Products," in Advances in Social Science, Education, and Humanities Research, 2018, pp. 175-180.

[2] T. S. Raffles, A History of Java, I. Cambridge: Cambridge University Press, 2010.

[3] Sunardi, Soerjowidagdo, H. Suratno, and W. Widra, Wisata Suci di Gunung Kawi. Jakarta: Marga Djaja, 1977.

[4] A. Prastowardoyo and K. Anam, Gunung Kawi: Fakta dan Mitos. Surabaya: Lingua Kata, 2009.

[5] E. F. Andalas, "Mitos Mbah Bajing Dalam Sastra Lisan Masyarakat Dusun Kecopokan Kecamatan Sumberpucung Kabupaten Malang,” State University of Malang, 2014.

[6] E. F. Andalas, "Dampak dan Fungsi Sosial Mitos Mbah Bajing bagi Kehidupan Spiritual Masyarakat Dusun Kecopokan Kabupaten Malang Jawa Timur,” Puitika, vol. 13, no. 1, pp. 21-31, 2017.

[7] D. Sulistyorini, B. Sudardi, Warto, and M. Wijaya, "Cultural Commodification: Representation of Pesarean of Mount Kawi as Cultural Tourism in Indonesian Mass Media," J. Intensive Stud. Lang. Lit. Art, Cult., vol. 1, no. 1, pp. 19-35, 2017.

[8] K. X. T. Yan and X. Zhu, "Commodification of Chinese Heritage Villages," Ann. Tour. Res., vol. 40, pp. 415-419, 2012.

[9] J. C. Cresswell, Research Design: Pendekatan Kualitatif, Kuantitatif, dan Mixed. Yogyakarta: Pustaka Pelajar, 2014.

[10] D. Mulyanto, Genealogi Kapitalisme: Antropologi dan Ekonomi Politik Pranata Eksploitasi Kapitalistik. Yogyakarta: Resist Book, 2012. 
[11] S. Muth, "Language Removal, Commodification and the Negotiation of Cultural Identity in Nagorno-Karabakh," in Conflict, Exclusion and Dissent in the Linguistic Landscape. Language and Globalization, R. R. and S. S.B, Eds. London: Palgrave Macmillan, 2015, pp. 77-99.

[12] S. Langegger, "Right-of-Way Gentrification: Conflict, Commodification and Cosmopolitanism," Urban Stud., vol. 53, no. 9, pp. 1803-1821, 2016.

[13] J. Lee, "Commodifying Magic: Cyber Shamans and Neoliberalised Culture in Korea," Cult. Relig., vol. 17, no. 3, pp. 295-311, 2016.

[14] K. Kalu, "From Commodity to Creativity: Exploring the Economic Potentials of the Nigerian Industry," Int. J. Bus. Econ. Perspect., vol. 12, no. 1, pp. 1-16, 2017.

[15] C. Bruckermann, "Trading on Tradition: Toursim, Ritual, and Capitalism in Chinese Village," Sage, vol. 42, no. 2, pp. 188-224, 2016.

[16] R. Afferni and C. Ferrario, "Religious Tourism and Italian Sacred Mounts: experiences of networking and co-operation at a UNESCO site," Int. J. Relig. Tour. Pilgr., vol. 4, no. 1, pp. 1-16, 2016.

[17] V. della Dora, "Infrasecular Geographies: Making, Unmaking and Remaking Sacred Space," Prog. Hum. Geogr., vol. 42, no. 1, pp. 44-71, 2018.

[18] D. H. Olsen and G. Wilkinson, "The Proliferation, Commercialization, and Secularization of the Seven Gods of Good Fortune Pilgrimages in Modern Japan," in 9th Annual International Religious Tourism and Pilgrimage Conference, 2017.

[19] A. Y. Chau, "The Commodification of Religion in Chinese Societies," in Modern Chinese Religion II: 1850 - 2015, New York: Brill, 20016, pp. 950-968.

[20] R. Raj and K. Griffin, Eds., Religious Tourism and Pilgrimage Management, 2nd ed. Oxfordshire: CABI, 2015.

[21] B.W. Setyawan and K. Saddhono, "Eret traditional ceremony as representation of spirit of mutual cooperation among coastal communities". Adv. Sci. Let. vol. 23 no.10, pp 99919992, 2017 